\section{The real deal}

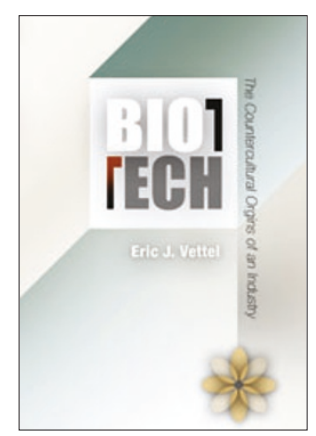

\section{Biotech: The Countercultural Origins of an Industry}

by Eric J. Vettel

University of Pennsylvania Press, 2006

Cloth, \$39.95, 296 pages

ISBN 0-8122-3947-4

\section{Reviewed by Harvey Bialy}

This is one of those rare books that, five minutes after picking it up and giving it a quick once-over, made me leave my desk in the workroom, prepare the espresso, move to a comfortable chair in the salon, light a Cohiba Esplendido and begin to read from page one. It is even one of those rarer volumes that I was still reading at page 200, when the cigar was more spent than splendid. And all this in spite of the ponderous back-cover quotes that could only have been chosen by a university press, and that I fear would frighten away many of the book's potential readers.

Far from a dry, or special interest-serving account, Eric Vettel's book makes us believe that he was actually there in the East Bay of California at the wild and crazy beginning of biotech, talking to all the people who in a few years would change the way biology was understood and practiced forever (though not necessarily for the better).

As the reader learns, the corporate ethos that governs the investor's world of today's biotech industry is a far cry from the spirit of mad capitalist and intellectual adventure that possessed the first entrepreneurs at its creation in the mid-1970s. It is the story of Don Glaser, Ron Cape and the rest of the University of California-Berkeley molecular biology and virus lab crew that invented the first biotechnology company ever, the great whale, Cetus, to showcase Don's "baby machine" for following "billions, almost" of individual bacterial colonies that most entranced me since I was a student in the Glaser lab at the time. A picture of the machine and Don as they appeared in the mid-1960s is included in the plates, and is by itself worth the price of the volume.

What is passed over or hinted at in other histories is here explored in depth and with the skill that comes from a sympathetic familiarity with his subject and subjects. The details of how one of the most

Harvey Bialy is a resident scholar at the Institute of Biotechnology of the Autonomous National University of Mexico. He was the scientific editor of Nature Biotechnology from 1983 to 1996, and is the author of Oncogenes, Aneuploidy and AIDS: A Scientific Life \& Times of Peter H. Duesberg. free-spirited bunch of 'homo scientifica' ever assembled could have transformed the scientific culture of both coasts simultaneously has never been told better. That the transformation quickly lost its luster for many, turned others into the corporate clones they probably always were in embryo and made biobiz monsters out of others are not its points, nor should they be, in my view. The dynamics of those events are common, and any history of them is bound to be a 'same old story.'

The trajectory that biotech describes is, however, a unique one. Never before had a 'theoretical' biology discipline been in a position to change the way entire global industries carried out product development and even did business. It was a heady time for even the headiest, and Vettel describes it as well as anyone I have ever read.

It joins Stephen Hall's Invisible Frontiers, which I reviewed for this journal's earlier incarnation ${ }^{1}$ — when I was a young man editing its scientific papers, biotech itself was still brand spanking new, and hope for the future was abundant-as the only history of the field I will keep and recommend. And now that I am old, considerably less sanguine and semi-retired in a mountain paradise in Mexico, I see it as the perfect complement to Hall's youthful history, being sober, and scholarly, and carefully written with the ring of utter truth.

1. Bialy, H. The fifty millicurie blues. Bio/Technology 5, 1165 (1987).

\section{New books of interest}

\section{Genomics \& Society: Legal, Ethical \& Social Dimensions}

edited by George Gaskell and Martin W. Bauer

Earthscan, 2006, 261 pp. hardcover, \$55

ISBN 1-84407-113-8

Target Validation in Drug Discovery

by Brian W. Metcalf and Susan Dillon

Elsevier, 2006, 296 pp. hardcover, $\$ 79.95$

ISBN 0123693934

Intellectual Property for Managers and Investors: A Guide to Evaluating, Protecting and Exploiting IP

Steven J. Frank

Cambridge University Press, 2006, 170 pp. hardcover, $\$ 60$

ISBN 0-521-85106-8 